\title{
Effect of Cover Crops Associated With Lettuce Production Under No-Tillage System
}

\author{
Indiamara Marasca ${ }^{1}$, Erení da Silva de Jesus ${ }^{1}$, Murilo Martins Batistuzzi ${ }^{2}$, Matheus Vinicius Abadia Ventura ${ }^{3}$, \\ Rose Luiza Moraes Tavares ${ }^{1}$, Antonio Carlos Pereira de Menezes Filho ${ }^{3}$ \& Jadson Belém de Moura ${ }^{4}$ \\ ${ }^{1}$ School of Agronomy, University of Rio Verde, Rio Verde, Brazil \\ ${ }^{2}$ School of Agronomy, State University of Mato Grosso do Sul, Cassilândia, Brazil \\ ${ }^{3}$ Postgraduate Program in Agricultural Sciences-Agronomy, Goiano Federal Institute, Rio Verde, Brazil \\ ${ }^{4}$ School of Agronomy, Evangelical Faculty of Goianésia, Goianésia, Brazil \\ Correspondence: Indiamara Marasca, School of Agronomy, University of Rio Verde, Rio Verde, Brazil. Tel: \\ 55-64-99916-1086. E-mail: marasca7@gmail.com
}

Received: November 3, $2021 \quad$ Accepted: December 1, $2021 \quad$ Online Published: December 15, 2021

doi:10.5539/jas.v14n1p78 URL: https://doi.org/10.5539/jas.v14n1p78

The research is financed by University of Rio Verde (UniRV) and National Council for Scientific and Technological Development $(\mathrm{CNPq})$.

\begin{abstract}
The use of cover crops has benefits for the chemical, physical and biological properties of the soil. However, together with the need for good vegetable productivity, considerable challenges arise in several regions of Brazil. The preparation of conventional soil for initiating no-tillage systems is necessary to create a management history and assimilate the benefits of the no-tillage system in vegetables, ensuring sustainable production. The objective of this research was to evaluate lettuce yield as a function of different cover crops as a function of resistance to soil penetration. The experiment was conducted in the horticulture sector of the University of Rio Verde, Rio Verde, Goiás, Brazil. The cover crops used were sunflower (Helianthus annuus), sunn hemp (Crotalaria juncea), and fallow, and the vegetable used was lettuce (Lactuca sativa). The variables analyzed were plant height and lettuce yield, straw decomposition, and soil resistance to penetration. The collected data were submitted to analysis of variance, and if significant, was compared by Tukey test $(\mathrm{p}<0.05)$ and regression analysis. The lettuce height in the different management systems showed no statistical differences. The decomposition of the straw presented accentuated degradation for the evaluated cover crops and the productivity was bigger in the straw of crotalaria and fallow. Soil resistance for cover crops was not greater than $2 \mathrm{MPa}$.
\end{abstract}

Keywords: vegetables, vegetation cover, management, production

\section{Introduction}

Lettuce (Lactuca sativa L.) is an herbaceous, annual plant belonging to the Asteraceae family, originating in Mediterranean regions with a mild climate, with a delicate structure with a small stem, on which the leaves are attached, being one of the most popular vegetables consumed widely in Brazil (Costa Júnior, 2017).

The management of crops in a no-tillage system include the following principles: ninimal soil disturbance; it has a permanent straw coverage, and crop rotations, including an annual cycle of biomass-producing plant species to assure for soil cover (Calegari, 2014)

Ground cover plants can provide several benefits for agricultural systems since the plant dry matter produced by them affects all soil properties, whether physical, chemical, or biological, providing an increase in crop productivity and mitigating greenhouse gas emissions into the atmosphere. The use of these plants becomes even more important in Cerrado soils, which are usually acidic, with low organic matter content and low fertility. They improve the quality of the soil in the region and enable the direct planting system through quality straw added to the soil (Silva et al., 2021).

The species used as cover crops absorb nutrients from deeper in the soil than typical commericail crops and then store thos nutrients in their plant material. When the cover crops decompose, they release these nutrients from 
their tissues, contributing to the increase in these elements in the more superficial soil layers, where the roots of commercial culture are concentrated. As a result, the process this sistem increases the nutrient availability nad improves fertilizer efficiency, which contributes to increased productivity of the subsequent crops (Forte et al., 2018).

Sunflower (Helianthus annuus L.) is a plant of the Asteraceae family, native to North America, cultivated as an ornamental and medicinal plant. It is often used in crop rotations and crop succession because it provides desirable agronomic characteristics, such as short life cycle, wide adaptability to environmental variations, high adaptability to variations in latitude, longitude, and photoperiod (Oliveira et al., 2017).

Sunn hemp (Crotalaria juncea L.) is a tall, $1.8 \mathrm{~m}$, annual legume with numerous branches, which is resistant to drought, fast-growing, and toxic to animals. It is a leguminous species recommended for soils of medium to high fertility and helpful in controlling nematodes, for a green manuring, and for cellulose production. With a short growth cycle, it is an excellent legume recommended for intercropping with perennial crops. Sunn hemp initiates flowering when the day length is less than twelve hours, and, therefore, considered a short-day plant (Boscolo et al., 2020).

Fallow areas are also called idle areas, being intended for soil cover, according to the National Supply Company (CONAB, 2020), or also known as winter fallow with invasive plants (Aita et al., 2001), or fallow as vegetation spontaneous (Pacheco et al., 2011).

The use of leguminous species, especially those considered green manures, are used to improve the nutritional availability within the production system in which they are used, helping to recover and/or increase the physical, chemical, and biological properties of the soil (Cardoso et al., 2014).

The legume species have a high nitrogen fixation capacity and agility in biomass production. The decomposition of dry matter of these species on the agroforestry floor keeps the soil covered in the that it increases the organic matter content, decreasing evapotranspiration (Silva et al., 2014).

The objective of this research was to evaluate plant height and lettuce yield, dry matter decomposition, and soil penetration resistance as a function of different cover crops.

\section{Method}

The experiment was carried out in the horticulture sector of the University of Rio Verde, Rio Verde, Brazil. The area is located at an altitude of 545 meters, latitude $23^{\circ} 25^{\prime}$ south and longitude $51^{\circ} 25^{\prime}$ west. The soil was classified as a dystrophic Red Latosol (Oxisol) of clayey texture (Embrapa, 2013).

The experiment was installed in randomized blocks with four treatments and five replications. Each repetition consisted of a plot 6 meters long and $3 \mathrm{~m}$ wide, totaling an area of $18 \mathrm{~m}^{2}$. The treatments consisted of cover crops being sunflower (Helianthus annus), sunn hemp (Crotalaria ochroleuca), and fallow (weeds). The number of cover crops was 50,000 and 30,000 ha ${ }^{-1}$ of sunflower and sunn hemp, respectively, according to the technical recommendations for each species (Carvalho et al., 2018).

Forty-five days after the cover crops emerged, they were sprayed with glyphosate $\left(960 \mathrm{~g} \mathrm{ha}^{-1}\right)$ and 2,4-D (720 g $\mathrm{ha}^{-1}$ ) to kill and desiccate the plant material, following technical recommendations by Valente et al. (2000) and Alves (2019). Prior to and following spaying the cover crops and fallow area with herbicides, no other management practices were used.

The American lettuce seedlings were produced in trays with the substrate. The lettuce seedlings with 4 permanent leaves were transplanted in the cover crop treatment areas 25 days after dissication. The lettuce plants were planted using a $0.50 \mathrm{~m}$ spacing between plants and $0.70 \mathrm{~m}$ between rows.

The variables analyzed were height plant, productivity, soil penetration resistance and percentage of straw decomposition methodology described by Chaila (1986). The plant height was measured using a graduated ruler, measuring the the height from the soil surface to the highest level of leaf foliage. Lettuces were harvested for yield analysis 45 days after planting. For statistical evaluation, the average of 10 plants from 4 replicate plots was used.

The collected data were subjected to analysis of variance, if significant, was compared by the Tukey test ( $p<$ 0.05 ) and by regression analysis using the Sisvar statistical software (Ferreira, 2019).

\section{Results}

There was no effect on the height of the lettuce plant concerning the different cover crops that were decaying. The decomposition of straw in the fallow was superior to the sunn hemp plant but showed a similar response 
with sunflower. The yield of lettuce covered with sunn hemp was superior to sunflower but with a similar response to fallow (Table 1).

Table 1. Plant height $(\mathrm{cm})$ and lettuce crop yield (grammes) and straw decomposition as a function of different cover crops and fallow.

\begin{tabular}{llll}
\hline Crops & Plant Height $(\mathrm{cm})$ & Straw Decomposition $(\%)$ & Yield $(\mathrm{g})$ \\
\hline Sunn hemp & $11.12 \mathrm{a}$ & $63.91 \mathrm{~b}$ & $0.36 \mathrm{a}$ \\
Sunflower & $10.14 \mathrm{a}$ & $69.08 \mathrm{ab}$ & $0.20 \mathrm{~b}$ \\
Fallow & $10.65 \mathrm{a}$ & $70.91 \mathrm{a}$ & $0.26 \mathrm{ab}$ \\
$\mathrm{CV}(\%)$ & $13.37 \%$ & $13.72 \%$ & $21.52 \%$ \\
\hline
\end{tabular}

Figure 1 shows the regression curve for lettuce height in a planting system subjected to different intercropping and fallow as a function of the crop cycle.

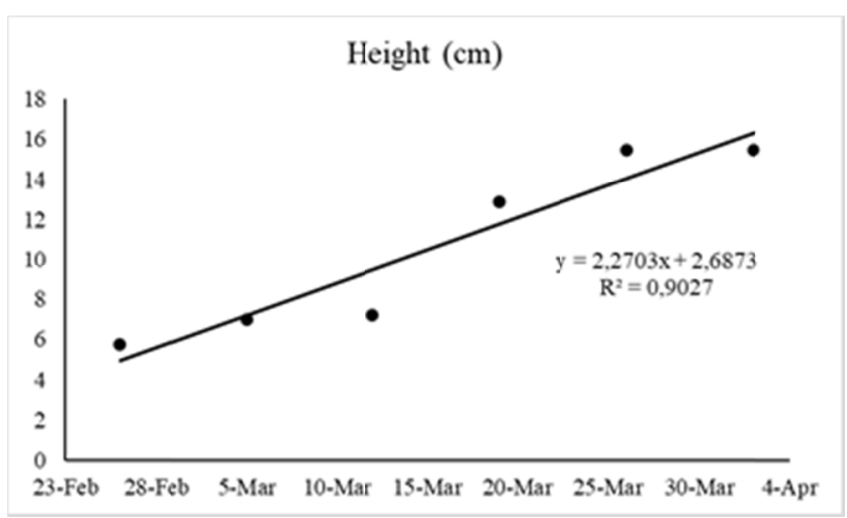

Figure 1. Height of lettuce plant under no-tillage system submitted to different intercropping and fallow

Figure 2 shows the regression curve for the decomposition of straw in a planting system subjected to different cover and fallow plants as a function of the crop cycle.

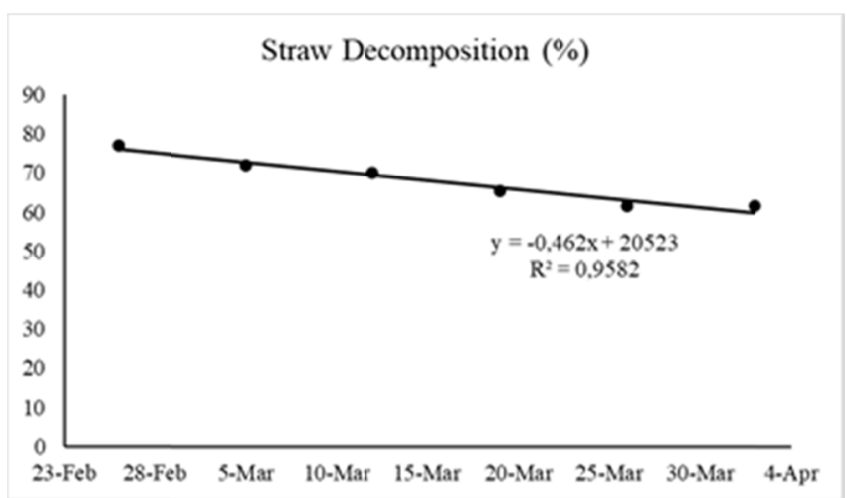

Figure 2. Straw decomposition curve in no-tillage system under different intercropping and fallow

Figure 3 shows the penetration resistance curve (MPa) in no-tillage system subjected to different intercropping and fallow. 

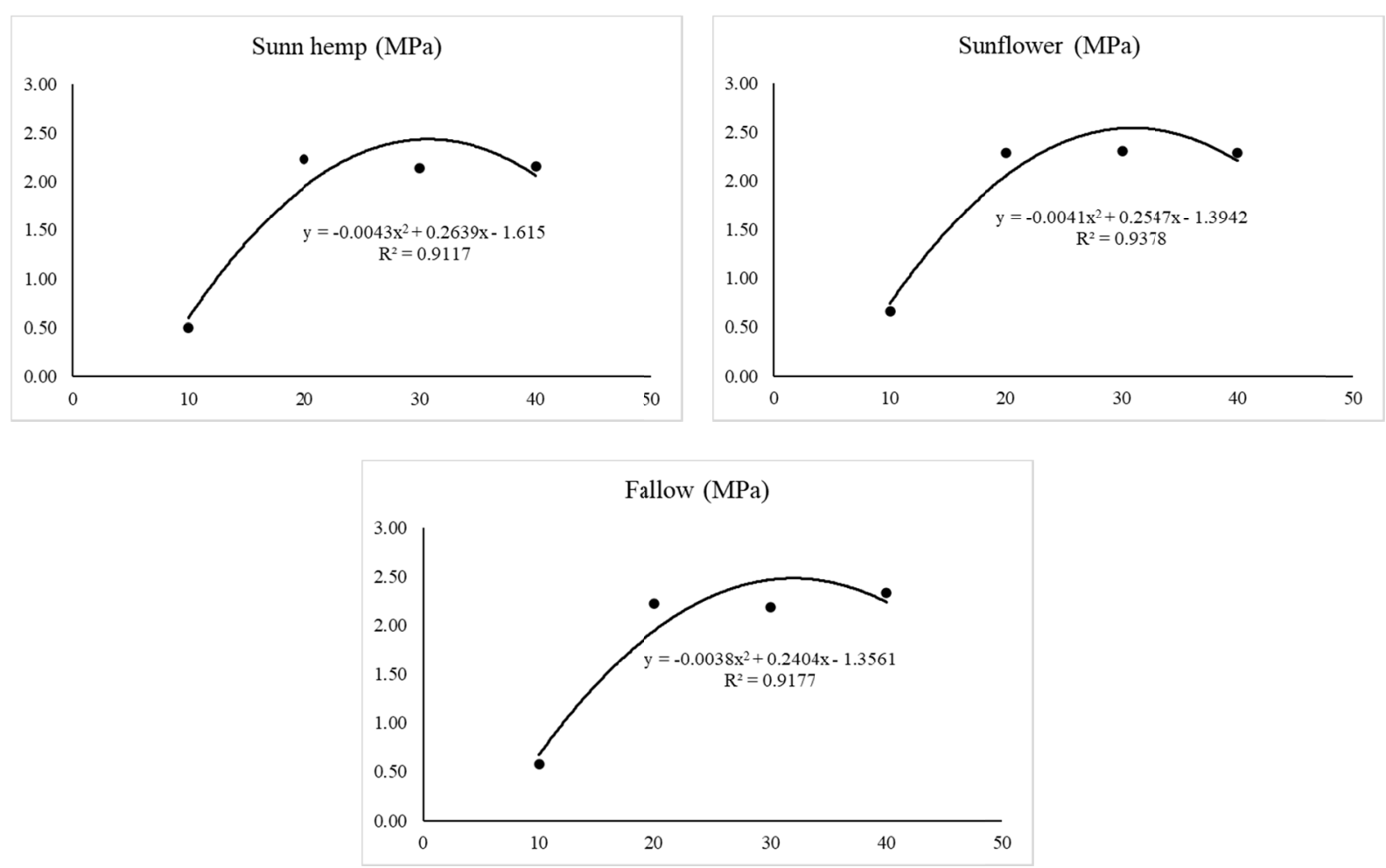

Figure 3. Penetration resistance curve (MPa) in no-tillage system subjected to different intercropping (sunn hemp and sunflower) and fallow

\section{Discussion}

Different plant varieties can be used as cover crops for no-tillage systems, depending on their morphological and subsequent crops (Bellinasso et al., 2021).

The total area of the experiment underwent harrowing; the fallow treatments presented a weed seed bank, reflecting a greater plant contribution from straw, like sunflower. Soil preparation exposes the seeds to light and favors the diffusion of oxygen and carbon dioxide out of the soil, incorporating organic residues and promoting soil dryness.

Thus, there are a greater temperature range, which favors nitrogen mineralization, seed germination, and changes in seed locations in the soil profile. At the same time, no-tillage systems keep weed seeds in the top $10 \mathrm{~cm}$ of the soil (Qasem, 2020).

The lettuce yields under the sunn hemp cover crop were significantly greater than the those under the sunflower cover crop, but not different than the fallow treatment. Either cover crop, sunn hemp or sunflower, produced greater lettuce yields than the fallow treatment (Table 1).

Although sunn hemp did not decompose rapidly, there was an increase in lettuce crop productivity in this treatment. According to Pedra et al. (2012), legumes have a lower $\mathrm{C} / \mathrm{N}$ ratio, which increases their decomposition rate, assuming that the mineralization process of nutrients is greater than the immobilization capacity.

Sousa et al. (2020), evaluating the foliar decomposition of species used in green manure and of economic interest in agroforestry systems, reported that the species used in green manure were the ones with the highest rate of decomposition for the two periods studied; thus, Gliricídia sepium and pig-bean species are recommended for the short-term nutrient return.

Almeida et al. (2020), evaluating lettuce crop productivity in a no-tillage system. It was observed that lettuce did not suffer any interference in the comparison between all the studied treatments. The treatment with transplanting in a no-tillage system at the highest speed showed the highest operational capacity of the set, being economically viable. 
Corrêa et al. (2020), evaluating the effects of cover crops such as Crotalaria juncea and corn. It was observed that after cutting the cover crops used, lettuce and baby corn, had similar productivity to that obtained after monoculture of sunn hemp.

The average soil pentration resistance sunn hemp, sunflower, and fallow were 1.76, 1.89, and $1.83 \mathrm{MPa}$, respectively. Vieira et al. (2021) found soil pentration resistance values of $1.67 \mathrm{MPa}$ for brachiaria and sunn hemp of 1.70 MPa in the first evaluation showed low soil compaction as a function of the other cover crops.

Rosa et al. (2020) evaluating soil compaction in sunflower crop found that it did not affect the number of sunflower leaves and shoot development, but had a negative impact on plant height, stem diameter, length and root dry mass, harming.

Silva et al. (2020), evaluating the penetration resistance of a dystrophic red-yellow latosol under different soil management systems, observed that the adoption of crop succession was beneficial in reducing soil penetration resistance compared to treatment with soybean succession with fallow.

The use of cover crops results in greater financial return by reducing costs, preserving soil health, increasing productivity, and the productive stability of economic crops. Therefore, it is noteworthy that the use of cover crops, isolated or mixed, in rotation with commercial crops, can make the agricultural systems of the Cerrado more efficient and sustainable (Silva et al., 2021). Thus, maintaining good soil preservation and systems that seek to conserve or increase organic matter, such as direct planting and intercropping, are promising options (Ventura et al., 2020).

As a result of this research, we concluded that the lettuce height produced in the different cover crop systems were not affected. In addition, straw decomposition was greater in the fallow treatment compared to the sunn hemp treatment. Lettuce yields were greater with the sunn hemp cover crop compared to sunflower cover crop, but not significant different from the fallow treatment. Soil resistance for cover crops was not greater than 2 MPa.

\section{Acknowledgements}

The University of Rio Verde for granting a scholarship to the first author and the National Council for Scientific and Technological Development (CNPq) for the scholarship to the second author.

\section{References}

Aita, C., Basso, C. J., Ceretta, C. A., Gonçalves, C. N., \& Da Ros, C.O. (2001). Plantas de cobertura de solo como fonte de nitrogênio ao milho. Revista Brasileira de Ciência do Solo, 25(1), 157-165. https://doi.org/10.1590/S0100-06832001000100017

Almeida, S. V., Baldini, L. F. G., Tecchio, M. A., \& Silva, P. R. A. (2020). Desempenho operacional e dados agronômicos de transplante manual e mecanizado na cultura da alface. Energia na Agricultura, 35(1), 29-37. https://doi.org/10.17224/EnergAgric.2020v35n1p29-37

Alves, L. W. R., Montagner, A. E. A. D., \& Pereira, J. F. (2019). Efeito de herbicidas na dessecação de plantas para cobertura do solo em Sistema de Plantio Direto no Cerrado Amapaense (Comunicado Técnico $n^{\circ} 157$ ). Macapá: Embrapa.

Bellinasso, A. V., Carvalho, I. R., Silva, J. A. G., Moura, N. B., Hutra, D. J., Loro, M. V., ... Lautenchleger, F. (2021). Cover crops and their relationship with the qualitative and quantitative atributes of soybeans. Brazilian Journal of Agriculture, 96(1), 294-313. https://doi.org/10.37856/bja.v96il.4260

Boscolo, A., Soares, W. S., Carvalho, J. B., \& Aparecido, C. F. (2020). Análise econômica do plantio de crotalária (Crotalaria juncea L.) para produção de sementes em áreas de reforma da cana-de-açúcar. Revista Funec Cientifica-Multidisciplinar, 9(11), 1-14. https://doi.org/10.24980/rfcm.v9i11.3520

Calegari, A. (2014). Perspectivas e estratégias para a sustentabilidade e o aumento da biodiversidade dos sistemas agrícolas com o uso de adubos verdes. In O. F. Lima Filho, E. J. Ambrosano, F. Rossi, \& J. A. D. Carlos (Eds.), Adubação verde e plantas de cobertura no Brasil: fundamentos e prática. Brasília: Embrapa, 1(1), 21-36.

Cardoso, R. A., Bento, A. S., Moreski, H. M., \& Gasparotto, F. (2014). Influência da adubação verde nas propriedades físicas e biológicas do solo e na produtividade da cultura de soja. Semina: Ciências Biológicas e da Saúde, 35(2), 51-60. http://doi.org/10.5433/1679-0367.2014v35n2p51 
Carvalho, A. M., Oliveira, A. D., Coser, T. R., Martins, A. D., Marchão, R. L., Pulronik, K., \& Sá, M. A. C. (2018). Plantas de cobertura do solo recomendadas para a entressafra de milho em sistema plantio direto no cerrado (Comunicado Técnico $n^{\circ} 181$ ). Planaltina: Embrapa.

Chaila, S. (1986). Metodos de evaluación de malezas para estudios de población y de control. Malezas, Buenos Aires, 14(2), 1-78.

CONAB (Companhia Nacional de Abastecimento). (2020). Acompanhamento da safra brasileira grãos (v. 7, Safra 2019/20-Décimo primeiro levantamento). Brasília: CONAB.

Corrêa, A. L., Abboud, A. C. S., Guerra, J. G. M., Aguiar, L. A., Araújo, E. S., \& Ribeiro, R. L. D. (2020). Efeito de pré-cultivos com crotalaria juncea e milho para Produção de minimilho e alface. Revista Brasileira de Agroecologia, 15(2), 74-80. http://doi.org/10.33240/rba.v15i2.23156

Costa Júnior, A. B. (2017) Cultivares de alface crespa roxa em diferentes épocas e ambientes de cultivo em Iranduba, $A M$ (p. 63). Manaus: Universidade Federal do Amazonas.

Embrapa (Empresa Brasileira de Pesquisa Agropecuária). (2013). Sistema brasileiro de classificação de solos (3rd ed.). Brasília: Embrapa.

Ferreira, D. F. (2019). Sisvar: A computer analysis system to fixed effects split plot type designs. Revista Brasileira de Biometria, 37(4), 529-535. https://doi.org/10.28951/rbb.v37i4.450

Forte, C. T., Galon, L., Beutler, N. A., Perin, G. F., Pauletti, E. S. S., Basso, F. J., Holz, C. M., \& Santin, C. O. (2018). Coberturas vegetais do solo e manejo de cultivo e suas contribuições para as culturas agrícolas. Revista Brasileira de Ciências Agrárias, 13(1), 1-10. http://doi.org/ 10.5039/agraria.v13i1a5504

Oliveira, S. L., Gomes Filho, A., Soares, D. P., Moreira, E. F., Chaga, L. M., Silva, G. G., \& Gomes, P. L. (2017). Dissimilaridade fenotípicaem genótipos de girassol cultivados no norte de Minas Gerais. Agri-Environmental Sciences, 3(2), 19-28.

Pacheco, L. P., Leandro, W. M., Machado, P. L. O. A., Assis, R. L. A., Cobucci, T., Madari, B. E., \& Petter, F. A. (2011). Produção de fitomassa e acúmulo e liberação de nutrients por plantas de cobertura na safrinha. Pesquisa Agropecuária Brasileira, 46(1), 17-25. https://doi.org/10.1590/S0100-204X2011000100003

Pedra, W. N., Pedrotti, A., Silva, T. O., Macedo, F. L., \& Gonzaga, M. I. S. (2012). Estoques de carbono e nitrogênio sob diferentes condições de manejo de um Argissolo Vermelho Amarelo, cultivado com milho doce nos tabuleiros costeiros de Sergipe. Semina: Ciências Agrárias, 33(6), 2075-2089. http://doi.org/ $10.5433 / 1679-0359.2012 \mathrm{v} 33 \mathrm{n} 6 \mathrm{p} 2075$

Qasem, J. R. (2020). Weed seed dormancy: The ecophysiology and survival strategies. In J. C. Jimenez-Lopez (Ed.), Seed dormancy and germination. London: IntechOpen. http://doi. org/10.5772/intechopen.88015

Rosa, A., Zanão Junior, L. A., \& Santos, R. F. (2020). Crescimento inicial do girassol sob níveis de densidades do solo. Acta Iguazu, 9(4), 102-108. https://doi.org/10.48075/actaiguaz.v9i4.25695

Silva, F. R. D., Albuquerque, J. A., \& Costa, A. D. (2014). Crescimento inicial da cultura da soja em Latossolo Bruno com diferentes graus de compactação. Revista Brasileira de Ciência do Solo, 38(6), 1731-1739. https://doi.org/10.1590/S0100-06832014000600008

Silva, L. I., Campos, M. C. C., Wadt, P. G. S., Cunha, J. M., Oliveira, I. A., Freitas, L., Santos, E. A. N., \& Brito Filho, E. G. (2020). Resistência à penetração de um Latossolo Vermelho-Amarelo Distrófico sob diferentes manejos e métodos. Revista do Departamento de Geografia, 40, 40-48. https://doi.org/10.11606/ eISSN.2236-2878.rdg.2020.162486

Silva, M. A., Nascente, A. S., Frasca, L. L. M., Rezende, C. C., Ferreira, E. A. S., De Filippi, M. C. C., ... Lacerda, M. B. (2021). Plantas de cobertura isolada e em mix para a melhoria da qualidade do soloe das culturas comerciais no Cerrado. Research, Society and Development, 10(12), e11101220008. http://doi.org/ 10.33448/rsd-v10i12.200081

Sousa, I. R. L., Pauletto, D., Lopes, L. S. S., Rode, R., Peleja, V. L., \& Freitas, B. B. (2020). Taxa de decomposição foliar de espécies utilizadas em sistemas agroflorestais. Revista Verde, 15(2), 118-126. https://doi.org/10.18378/rvads.v15i2.6734

Valente, T. O., Edson, I., Rodrigues, T., \& Cavazzana, M. A. (2000). Efeito de diferentes doses de 2,4-D, aplicado como dessecante em varios intervalos antes da semeadura direta da soja, para manejo em ambiente de cerrados. Revista Brasileira de Herbicidas, 1(2), 185-200. https://doi.org/10.7824/rbh.v1i2.335 
Ventura, M. V. A., Baliza, L. M., Pereira, L. S., Costa, E. M., Batista, H. R. F., \& Trombela, N. T. S. (2020). Microbial diversity as an indicator of soil quality in corn consortiums with forage. Academia Journal of Agricultural Research, 8(7), 206-210. https://doi.org/10.15413/ajar.2020.0119

Vieira, I. D., Marasca, I., Solino, A. J. S., Santos, G. O., \& Tavares, R. L. M. (2021). Compactação do solo em cultivo de repolho roxo no sistema plantio direto. Enciclopédia Biosfera, 18(35), 56-65. https://doi.org/10.18677/EnciBio_2021A5

\section{Copyrights}

Copyright for this article is retained by the author(s), with first publication rights granted to the journal.

This is an open-access article distributed under the terms and conditions of the Creative Commons Attribution license (http://creativecommons.org/licenses/by/4.0/). 